REPORTS OF MORPHOLOGY
Official Journal of the Scientific Society of Anatomists,
Histologists, Embryologists and Topographic Anatomists
of Ukraine
journal homepage: https://morphology-journal.com

\title{
Effect of bougienage and washing of the pancreatic duct on the course of experimental acute pancreatitis
}

Kostyuk G.Ya., Kostyuk O.G., Burkov M.V., Fomina L.V., Golubovsky I.A., Kostyuk V.G. National Pirogov Memorial Medical University, Vinnytsya, Ukraine

\author{
ARTICLE INFO \\ Received: 22 November, 2017 \\ Accepted: 11 January, 2018
}

UDC: $616-089.819 .5: 616.37: 616.37-$ 002:612.0.8

\section{CORRESPONDING AUTHOR \\ e-mail: burkov@vnmu.edu.ua} Burkov M.V.
The presence of many hypotheses of the development of acute pancreatitis such as pancreatic ducthypertension, pancreatic reflux, vascular, allergic, neuro-reflex, infectious, etc. confirm the lack of a clear understanding of the development mechanisms of this pathology, and hence inaccuracy in the treatment and negative consequences. The purpose of this study was to investigate the effect of bouginage and flushing of the pancreatic duct on the course of experimental acute pancreatitis. Experiments were carriedouton 12 dogs, for which amodel of pancreatitis wascreated byautobileadministration into the pancreas duct. Animals were divided into four groups, 3 animals per each, with the term of deduce from the testin one, three, seven days and six months respectively. Before the pancreas ductperfusion, itwas injected with polyvinylchloride bougie that was removed through the incision in the distal part of the pancreas duct. Such manipulation allowed to conduct duct washing with medicinal substances at a pressure of 0.49-0.6 kPa and confirmed the assumption that in acute pancreatitis, filling of pancreas duct with condensed protein masses was observed, and this, changes theapproach notonly to the establishment of the pathogenetic link in the process of acute pancreatitis development, but also to its treatment. The duct was washed once. The common comprehensive drug therapy was carried out in dogs within the next five, six days. At the end of the first day, out of the 12 dogs, nine stood independently, the rest - on the second day. On the third day, all animals drank water, responded to stimuli. On the fifth day they were active, taking liquidfeed. On the seventh day on their behavior and feeding manner the dogs of this group didnot differ from healthy ones. To studymorphological changes in pancreas after ductwashing, three dogs were withdrawn from the test in one day. Atautopsy effusion in peritoneal cavity was not observed. The left lobe of pancreas was a little bit shorter. Place of dissection of the tissues of the pancreas and the duct is covered with a blood clot. In the area of duodenum dissection, isolated patches of steatoenecrosis retained. Microscopically, in the ductarea dissection changes in pancreas tissues, in general, were the same as in duct dissection withoutperfusion. At the same time, the plethora for this term was great. Necrotic centers of parenchyma were isolated and with moderate neutrophilic infiltration. Distant from the dissection zone in pancreas tissues therewere minor focal hemorrhages with a violation of its structure, however, hyperplasia, fociofneutrophilic infiltration of the interstitial connective tissue wereless manifestated. In the proximal part of the duct, the pancreas tissue retained moderate plethora. In addition, there were small foci of hemorrhages with a violation of the structure of individual acinus and slight neutrophilic infiltration in interstitial connective tissue. Thelatter was also marked by theaccumulation of macrophages and the proliferation of fibroblasts, therewere isolatedareas of hemorrhages. Inintactpart there wasaninsignificant edema of interstitial connective tissue. As a result of the conducted experiments, we were convinced of the effectiveness of this method of treating acute pancreatitis.

Keywords: acute pancreatitis, bougie of the pancreatic duct.

\section{Introduction}

The presence of many hypotheses of the development of acute pancreatitis such as duct hypertension, pancreatic reflux, vascular, allergic, neuro-reflex, infectious, pathobiochemical and others means the lack of a clear understanding of the mechanisms of development of this pathology, and hence inaccuracy in the treatment and 
negative consequences $[13,14,15,16,17,18]$.

The leading role of duct hypertension in the pathogenetic mechanism of the development of acute pancreatitis is indicated by many researchers, as in the past century, and modern $[3,6,8,9,10,11,12]$.

Significant interest in this regardare the studies conducted by Napalkov P.M. with co-authors [7]. Describing drainage operations on the pancreas duct in acute pancreatitis, they noted that hypertension develops in all forms of acute pancreatitis. In addition, in patients with progressive pancreatic necrosis, according to their data, there was a significant increase in pressure in the pancreatic duct with a sharp decrease in secretion of pancreatic juice. For the rejection of the envelope epithelium in the pancreas duct in animals that died from pancreatic necrosis in 14 days pointed out Vladimirov V.G. and co-authors [1], which, according to their data, indicates a violation of the protein synthesizing function of acinar cells.

Other authors in their studies conducted on four dogs, after induction of acute pancreatitis, who died within the first day of pancreatic necrosis, observed in its pancreas duct obturation with condensed protein mass $[2,4,5]$.

Thus, if acute pancreatitis, in the first stages of its development, there is occlusion of the duct with protein masses, then there was an idea in some way to restore its patency, and to investigate how the restoration of patency will affect the course of the disease.

The purpose of this study was to investigate the effect of bougienage and duct washing of the pancreas on the course and the morphological state of the pancreas in experimental acute pancreatitis.

\section{Material and methods}

Experiments were carried out on 12 dogs, which created a model of pancreatitis by introducing autobile into the pancreas duct. Animals were divided into four groups, 3 animals per each, with the term of withdrawal from the test after one, three, seven days and six months respectively. Before perfusion of the pancreas duct, it was injected with polychlorinated bougie that was removed through the incision in the distal region of the pancreas duct. Such manipulation allowed conducting duct washing with medicinal substances at a pressure of $0.49-0.6 \mathrm{kPa}$, that is several times less than the working pressure in the duct. In addition, it confirmed the assumption that in acute pancreatitis, filling of the pancreas duct with condensed protein masses is observed, and this, as we have been sure, changes the approach not only to the establishment of the pathogenetic link in the development of acute pancreatitis, but also to its treatment. The duct was washed one time. Animals were given a common, comprehensive drug therapy within the next five to six days.

For all 12 animals pancreatic ducts were washed with a therapeutic fluid consisting of $0.25 \%$ Novocaine solution $10 \mathrm{ml}$, Fibrinolysin $-3 \mathrm{ml}$, and 10000 antitrypsin units of Contrykal- $2 \mathrm{ml}$. The flushing was carried out at a rate of 20-
30 drops per minute. After 14-20 minutes after duct washing, the pancreas decreased markedly in width, foci of hemorrhage took a pale coloration, areas of the gland of the usual color appeared, the number and area of foci and steatoenecrosis did not increase. After perfusion, the catheter was removed. To the place of dissection of the gland and duct was fed drainage tube. The abdominal cavity was sewn in a layer.

In the postoperative period, the withdrawal from the drainage tube was negligible - from 2 to $12 \mathrm{ml}$. In addition, in almost all animals, they were observed, mainly during the first day after the operation.

\section{Results}

Of the 12 dogs, at the end of the first day, nine stood up, the rest - on the second day. On the third day, all animals drank water, responded to stimuli. On the fifth day they were active, taking liquid feed. On the seventh day on the behavior and eating of dogs of this group did not differ from healthy ones.

To study morphological changes in the pancreas after duct washing, three dogs were withdrawn from the experiment after one day. At the intersection effusion in the peritoneal cavity was not observed. The left part of the pancreas was somewhat reduced in length. Place of dissection of the tissues of the pancreas and the duct was covered with a clot of blood. In the area of the autopsy of the duodenum, isolated patches of steatoenecrosis persisted.

Microscopically, in the region of dissection of the duct changes in the pancreas, in general, were the same as in the dissection of the duct without perfusion. At the same time, at this term was marked only large foci of plethora. Necrotic centers of parenchyma were isolated and with moderate neutrophilic infiltration. Distant from the dissection zone in the pancreas tissue there were minor focal hemorrhages with a violation of its structure, however, plethora, foci of neutrophilic infiltration of the interstitial connective tissue were less pronounced. In the proximal part of the duct, the tissue of the pancreas retained moderate plethora. In addition, there were small foci of hemorrhages with a violation of the structure of individual acinus and slight neutrophilic infiltration in the interstitial connective tissue. The latter also marked the accumulation of macrophages and the proliferation of fibroblasts. Although the wall of the ducts was not tense in their lumen, as in the dissection of the duct without rinsing, there were isolated foci of hemorrhages. In intact part there was an insignificant edema of interstitial connective tissue.

Thus, in dogs of this group perfusion of the pancreas duct by Novocaine-Fibrinolysin- Contrykal solution allowed to reduce the number of foci of hemorrhage, necrosis and neutrophil infiltration. It allowed to remove the tension of the duct wall in the proximal part of the section of the pancreas and stimulate, albeit not to a large extent, processes of productive inflammation.

At the autopsy of 3 dogs that were withdrawn from the test in three days, macroscopically observed the same 
changes as in dogs, which performed only the dissection of the duct with the same term of experiment.

During histological examination of the region of dissection of the pancreas duct in it tissues, moderate plethora and edema were maintained. Exudative phenomena, when compared with the first day, were slightly expressed. The layers of the connective tissue became larger and denser due to the formation of fibrous structures and cell proliferation. When coloring tissues by Van Gieson's, intermediate connective tissue was characterized by an increase in the number of collagen fibers. At this time there was no abundant infiltration by neutrophils of the pancreas tissue. Attention was paid to the active organization of small foci of necrosis and hemorrhages. State of ducts was very special: they were semi-closed, their epithelium was swollen with hypochromic nuclei. In the lumen, there was a dense eosinophilic substrate that contained isolated detached cells. The proliferation of cells in the middle of the lacrimal ducts and interstitial connective tissue were markedly pronounced. Parenchyma in general retained the usual structure.

Similar changes were observed in the distal from the dissection pancreas duct, however, the phenomena of productive inflammation were expressed not so intensively. Gap of the duct was characterized by the expansion and presence of dense eosinophilic masses. In the proximal direction ( $3 \mathrm{~cm}$ from the dissection of the duct) there was a well-defined organization of mosaic necrosis. Characteristic was the lack of pronounced changes in the lumen of the ducts and parenchyma.

Intact part, except for insignificant plethora, was no different from the normal structure.

Thus, in dogs of this group, in comparison with the previous term of research, there were not observed the expressed phenomena of acute inflammation. Significantly more intensive was the proliferative process. Unlike dogs, where only one dissection of the duct of the pancreas was performed, the organization of small foci of necrosis and hemorrhages was more active. Gap of the duct outside the dissection zone was unobtrusive, whereas in the comparative group of animals, during this period, the eosinophilic masses and erythrocytes were partially stored there. Significantly fewer changes were noted in the proximal section of the pancreas, i.e. in the part of the gland that was washed out.

\section{Discussion}

During examination abdominal organs of dogs that had been withdrawn from the experiment after seven days, the same changes were observed in the same way as dogs in this period without flushing the duct. Results similar to ours, can be found in other authors who described the destructive forms of pancreatitis without treatment $[2,6]$. However, in the literature available to us, we did not meet the description of the method of treatment similar to our $[1,7,12,13]$. However, despite the fact that the microscopically in the pancreas of these dogs marked changes similar to those in the comparative group. Nevertheless, it should be noted that in the group of animals being studied, the growth of connective tissue was more moderate, there was regeneration of acinus without changes in the ducts of the pancreas. In the distal from the dissection of the duct region of the gland, the process of atrophy of the parenchyma was significantly pronounced.

Thus, in dogs removed from the test after 7 days, unlike the previous term, in the proximal part from the dissection of the duct of the pancreas, a less pronounced productive inflammation of the indurational nature was observed, no changes in the parenchyma of the pancreas were observed. Consequently, bougienage with subsequent perfusion of the pancreatic duct Novocaine-Fibrinolysin-Contrykal solution, along with improving its permeability, promotes the active process of restoring pancreatic tissue and eliminating the effects of acute inflammation during the first day. In other words, the faster the conditions for the movement of pancreatic juice develop without any delay in acute pancreatitis, the sooner the restoration of pathological processes in the pancreas passes, with which other authors agree $[4,5,15]$. If there were changes, they were without significant violations of its structure.

To confirm this thesis, it was necessary to follow the state of the pancreas in the long term of treatment of acute pancreatitis. For this purpose, three dogs after bougienage followed by pancreatic duct washing with NovocaineFibrinolysin- Contrykal solution were withdrawn from the test six months later. At the animal's autopsy, attention was paid to preserving the form of the pancreas to the point of dissection of its tissues and ducts. The other part of the gland was presented in the form of a dense strain.

During microscopic examination of the dissection zone (between stored and atrophied parts of the pancreas), attention was paid to the preservation of the parenchyma of the gland, in which, along with the enlarged acinus, there was observed acinus with a narrow lumen. It is possible that this state reflects the functional cyclicity in the accumulation and release of pancreatic juice, which is observed in normal functioning of the pancreas. In the studied area, the phenomena of minor sclerosis between the pancreas part and in the periductal connective tissue are sometimes fixed.

In the proximal from the boundary part of the direction, a clear structure of acinus and intercellular ducts was detected. Characteristic was also the absence of intra acinus sclerosis. However, the signs of the latter were observed in periductal tissue. The area of the body and the right part of the pancreas did not differ from the normal structure.

Thus, after 6 months in animals after bougienage followed by flushing of the pancreatic duct with Novocaine-FibrinolysinContrykal solution observed stabilization of the formation of connective tissue. The more pronounced growth of the latter occurred in periductal tissue.

However, despite insignificant sclerosis of the circulatory connective tissue, bougienage with subsequent duct washing is an effective measure in the complex treatment of experimental acute pancreatitis, it allows to preserve the 
pancreatic tissue, which distinguishes it favorably from other methods of treating acute pancreatitis.

The prospect of further research may be the use of this technique in clinical settings.

\section{Conclusions}

Bougienage with the subsequent perfusion of the pancreas duct with a medicinal mixture has a positive effect on the course and outcome of experimental acute pancreatitis, namely:

\section{References}

[1] Vladimirov, V. G., \& Sergienko, V. I. (1986) Acutepancreatitis (experimental and clinical study). M.: Medicina.

[2] Kaliev, A. A. (2013). Macromicroscopic anatomy and internal organ histoptopography of the pancreas in acute destructive pancreatitis. Morfologicheskie vedomosti, 2, 33-37.

[3] Korot'ko, G. F. (2014). Secretion of the pancreas: from thePavlov's elements to the present time (Tothe 110-anniversary of Nobel Prizeaward to I.P. Pavlov). Russian Journal of Gastroenterology, Hepatology, Coproproctology, 24(3), 4-12. Retrieved from www.gastro-j.ru/files/_2014_3_s1_1406994714.pdf

[4] Kostiuk, G. Y. (2014). Consequences of high pressure in the pancreas duct. Bulletin of the Vinnytsia National Medical University, 18(1), 30-32.

[5] Kostiuk, G. Y. (2017). Perfusion of ducts of the pancreas in the treatment of acute pancreatitis. Materials of the scientific and practical conference "Applied aspects of morphology". Vinnytsia.

[6] Lonsky, L. Y. (2015). Morphological changes in pancreas in edema and destructive forms of acute pancreatitis. Bulletin of the Vinnytsia National Medical University, 19(1), 248-251.

[7] Napalkov, P. N., \& Artem'eva, N. N. (1984). Surgical treatment of combined obstruction of the terminal section of the choledochus and duct of the pancreas. XXX All-Union Congress of Surgeons. Minsk.

[8] Peter A., Banks, (1982). Pancreatitis. Moscow: Medicine.

[9] Savel'ev, V. S., Buyanova, V. M., \& Ognev, Y. V. (1983). Acute pancreatitis. Moscow: Medicine.

[10] Filin, V. I. (1982). Acute diseases and pancreatic injury. Moscow: Medicine.

[11] Aggarwal, A., Manrai, M., \& Kochhar, R. (2014). Fluid resuscitation in acute pancreatitis. World J. Gastroenterol. 20(48), 18092-103. doi: 10.3748/wjg.v20.i48.18092.
1. Lack of death of animals;

2. Effectively relieves pressure in the duct system of the pancreas, as a result of which the spread of the pathological process is prevented;

3. Eliminated duct obturation of the pancreas with dense protein masses;

4. Structural changes in the duct, tissues, vessels of the pancreas are not developing;

5. Saved in the functional sense of the proximal part of the pancreas from the dissection of the duct.

[12] Dua, M. M., Worhunsky, D. J., Malhotra, L., Park, W. G., Poultsides, G. A., Norton, J. A., \& Visser, B. C. (2017). Transgastric pancreatic necrosectomy-expedited return to prepancreatitis health. J. Surg. Res., 219, 11-17. doi: 10.1016/j.jss.2017.05.089.

[13] Glabay, V. P., Cridnev, O. V., Arkharov, A. V., Bykov, A. N., Kaprin, I. A., \& Muslimov, B. G. (2017). Complications of the 'open' surgeries for severe acute pancreatitis. Surgery, 10, 72-76. doi: 10.17116/hirurgia20171072-76.

[14] Hancerli, Y., Kaplan, M., Tanoglu, A., Yesilbas, S., Kucukodaci, Z., Yildirim, M., ... Sakin, Y. S. (2017). Efficacy of tocilizumab treatment in cerulein-induced experimental acute pancreatitis model in rats. Turk. J. Gastroenterol., 28(6), 485-491. doi: 10.5152/tjg.2017.16738.

[15] Huang, Q., Shao, F., Wang, C., Qi, W., Qiu, L. J., \& Liu, Z. (2018). Nasobiliary drainage can reduce the incidence of post-ERCP pancreatitis after papillary large balloon dilation plus endoscopic biliary sphincterotomy: a randomized controlled trial. Scand. J. Gastroenterol., 53(1): 114-119. doi: 10.1080/00365521.2017.1391329.

[16] Janisch, N. H., \& Gardner, T. B. (2016). Advances in Management of Acute Pancreatitis. Gastroenterol. Clin. North Am. 45(1), 1-8. doi: 10.1016/j.gtc.2015.10.004.

[17] Kolodecik, T. R., Reed, A. M., Date, K., Shugrue, C. A., Patel, V., Chung, S. L. ... Gorelick, F. S. (2017). The serum protein renalase reduces injury in experimental pancreatitis. J. Biol. Chem., 292(51), 21047-21059. doi: 10.1074/ jbc.M117.789776.

[18] Manohar, M., Verma, A. K., Upparahalli Venkateshaiah, S., Goyal, H., \& Mishra, A. (2017). Food-Induced Acute Pancreatitis. Dig. Dis. Sci., 62(12), 3287-3297. doi: 10.1007/s10620-017-4817-2.

\section{ВПЛИВ БУЖУВАННЯ ТА ПРОМИВАННЯ ПРОТОКИ ПІДШЛУНКОВОЇ ЗАЛОЗИ НА ПЕРЕБІГ}

ЕКСПЕРИМЕНТАЛЬНОГО ГОСТРОГО ПАНКРЕАТИТУ

Костюк Г.Я., Костюк О.Г., БУрков М.В., Фоміна Л.В., Голубовський І.А., Костюк В.Г.

Наявність багатьох гіпотез розвитку гострого панкреатиту, таких як протокова гіпертензія, панкреатичний рефлюкс, судинна, алергічна, нервово-рефлекторна, інфекційна та інших говорить про відсутність чіткого розуміння механізмів розвитку даної патології, а, звідси, неточність у лікуванні і негативні наслідки. Метою даного дослідження було вивчити вплив бужування та промивання протоки підшлункової залози на перебіг та морфологічний стан підшлункової залози при експериментальному гострому панкреатиті. Досліди були проведені на 12 собаках, котрим створили модель панкреатиту шляхом введення аутожовчі у протоку підшлункової залози. Тварин поділили на 4 групи, по 3 тварини в кожній, з терміном виведення з досліду через 1, 3, 7 діб і через 6 місяців відповідно. Перед перфузією протоки підшлункової залози в неї вводили поліхлорвініловий буж, який через розріз в дистальному відділі протоки підшлункової залози видаляли. Така маніпуляція дозволила проводити промивання протоки лікувальними речовинами при тиску 0,49-0,6 кПа і підтвердила припущення, що при гострому панкреатиті спостерігається виповнення протоки підшлункової залози згущеними білковими масами, а це, як ми впевнились, міняє підхід не лише до встановлення патогенетичної ланки в розвитку гострого панкреатиту, а й до його лікування. Протоку промивали 1 раз. Тваринам проводили загальноприйняту комплексну медикаментозну терапію протягом 5-6 наступних днів. Із 12 собак по закінченню першої доби самостійно підіймалося 9, решта - на другу добу. На третю добу всі тварини пили воду $і$ реагували на подразники. На 5 добу вони були активними, приймали рідкий корм. На 7 добу по поведінці й прийому їжі 
собаки даної групи не відрізнялися від здорових. Для вивчення морфологічних змін у підшлунковій залозі після промивання протоки 3 собаки були виведенні із досліду через 1 добу. Випоту в очеревинній порожнині не спостерігалося. Ліва доля підшлункової залози була дещо зменшена у довжину. Місце розсічення тканин підшлункової залози і протока прикрита згустком крові. В області розтину 12-ти палої кишки зберігалися поодинокі плями стеатонекрозу. Мікроскопічно в області розсічення протоки зміни тканин підшлункової залози були аналогічними розсіченню протоки без перфузії. Разом із тим, повнокров'я на цей термін відмічалося тільки великовогнищеве. Некротичні вогнища паренхіми були поодинокими із помірною нейтрофільною інфільтрацією. Дистальніше зони розсічення в тканині підшлункової залози спостерігалися незначні вогнищеві крововиливи з порушенням ї̈ структури, однак повнокров'я, вогнища нейтрофільної інфільтрації у міжчасточковій сполучної тканини були менше вираженими. У проксимальній від розсічення частині протоки тканина підшлункової залози зберігала помірне повнокров'я. Крім того, в ній зустрічалися мілкі вогнища крововиливів з порушенням структури окремих ацинусів $i$ незначною нейтрофільною інфільтрацією в міжчасточковій сполучній тканині. В останній відмічались також скупчення макрофагів іпроліферація фібробластів, зустрічались поодинокі вогнища крововиливів. В інтактній долі спостерігали незначний набряк міжчасточкової сполучної тканини. В результаті проведених експериментів ми переконалися в ефективності даного методу лікування гострого панкреатиту.

Ключові слова: гострий панкреатит, бужування протоки підшлункової залози.

\section{ВЛИЯНИЕ БУЖИРОВАНИЯ И ПРОМЫВАНИЯ ПРОТОКА ПОДЖЕЛУДОЧНОЙ ЖЕЛЕЗЫ НА ТЕЧЕНИЕ ЭКСПЕРИМЕНТАЛЬНОГО ОСТРОГО ПАНКРЕАТИТА \\ КостюК Г.Я., Костюк А.Г., Бурков Н.В., Фомина Л.В., Голубовский И.А., Костюк В.Г.}

Наличие многих гипотез развития острого панкреатита, таких как протоковая гипертензия, панкреатический рефлюкс, сосудистая, аллергическая, нервно-рефлекторная, инфекционная и других говорит об отсутствии четкого понимания механизмов развития данной патологии, а отсюда неточность в лечении и негативные последствия. Целью данного исследования было изучить влияние бужирование и промывание протоки поджелудочной железы на течение и морфологическое состояние поджелудочной железы при экспериментальном остром панкреатите. Опыты были проведены на 12 собаках, которым создали модель панкреатита путем введения аутожелчи в проток поджелудочной железы. Животных разделили на 4 группы, по 3 животных в каждой, со сроком вывода из опыта через 1, 3,7 дней и 6 месяцев соответственно. Перед перфузией протока поджелудочной железы в нее вводили полихлорвиниловый буж, который через разрез в дистальном отделе протока поджелудочной железы удаляли. Такая манипуляция позволила проводить промывание пролива лечебными веществами при давлении 0,49-0,6 кПа и подтвердила предположение, что при остром панкреатите наблюдается заполнение протока поджелудочной железы сгущенными белковыми массами, а это, как мы убедились, меняет подход не только к установлению патогенетической звена в развитии острого панкреатита, а и к его лечению. Проток промывали 1 раз. Животным проводили общепринятую комплексную медикаментозную терапию в течение 5-6 последующих дней. Из 12 собак по окончании первых суток самостоятельно поднимались 9, остальные - на вторые сутки. На третьи сутки все животные пили воду, реагировали на раздражители. На 5 сутки они были активными, принимали жидкий корм. На 7 сутки по поведению и приему пищи собаки данной группы не отличались от здоровых. Для изучения морфологических изменений в поджелудочной железе после промывания протока, 3 собаки были выведены из опыта через 1 сутки. Выпота в брюшинной полости не наблюдалось. Левая доля поджелудочной железы была несколько уменьшена в длину. Место рассечения тканей поджелудочной железы и протока прикрыта сгустком крови. В области вскрытия 12-перстной кишки сохранялись редкие пятна стеатонекроза. Микроскопически в области рассечения протока изменения тканей поджелудочной железы были аналогичными рассечению протока без перфузии. Вместе с тем, полнокровие в этом сроке отмечалось только крупноочаговое. Некротические очаги паренхимы были единичными и с умеренной нейтрофильной инфильтрацией. Дистальнее зоны рассечения в ткани поджелудочной железы наблюдались незначительные очаговые кровоизлияния с нарушением ее структуры, однако полнокровие, очаги нейтрофильной инфильтрации в междольковой соединительной ткани были меньше выражены. В проксимальной от рассечения части протока ткань поджелудочной железы сохраняла умеренное полнокровие. Кроме того, в ней встречались мелкие очаги кровоизлияний с нарушением структуры отдельных ацинусов и незначительной нейтрофильной инфильтрацией в междольковой соединительной ткани. В последней отмечались также скопления макрофагов и пролиферация фибробластов, встречались единичные очаги кровоизлияний. В интактной доле наблюдали незначительный отек междольковой соединительной ткани. В результате проведенных экспериментов мы убедились в эффективности данного метода лечения острого панкреатита.

Ключевые слова: острый панкреатит, бужирование протока поджелудочной железы. 